\title{
80 Years of the Journal of Parapsychology: An Historical Overview
}

\author{
John Palmer ${ }^{1}$
}

Rhine Research Center

\begin{abstract}
In this invited article, the author reviews the history of the Journal of Parapsychology from its inception in 1937 to 2017 . The focus is on published controversies and debates with critics outside the field of parapsychology, JP publication policy, and the changes in editorship.
\end{abstract}

Keywords: Journal of Parapsychology, parapsychology, publication policy

When Etzel Cardeña invited me to write a history of the Journal of Parapsychology (JP), I immediately knew that I had to make some difficult decisions about how to cover journal content. If I ignored the content and stuck to process issues such as changes in editorship and publication policy, the finished product would be but a few pages. On the other hand, if I tried to cover all the content, the paper would be way too long, even if I said so little about each contribution that the summaries would not be particularly useful. So it quickly became evident that I had to be selective about the content I covered. I decided to focus primarily on two classes of contributions: (a) articles about the JP per se, including summaries of content over a circumscribed period of time and publication policies, and (b) special sections of a particular issue or successive issues comprised of series of papers on a given topic or theme. Most of these represented controversies about the status of the evidence for psi. I tried to describe these sections in a matter-of-fact way and avoid injecting my own opinions and prejudices. As the piece is historical, I will order the paragraphs more-or-less chronologically.

As noted by Mauskopf and McVaugh (1980) in their definitive review of the early years of the Parapsychology Laboratory at Duke, J. B. Rhine was eager to establish a scientific journal for parapsychology that he felt would provide legitimacy and mainstream recognition of the research. It began in 1937, with Rhine and the famous psychologist William McDougall, chairman of the new Duke psychology department, as editors. The journal was enabled by funding from Alice Crunden and then from Charles Ozanne, both of whom also gave considerable money to fund research at the laboratory. The editor was originally intended to be the noted psychologist Gardner Murphy, but he withdrew as he felt that the research papers scheduled for the next issue were of insufficient quality. Although some recognition was achieved in that articles in the journal were referenced in Psychological Abstracts from the outset, psychologists at the time could not be enticed to publish in it (Mauskopf \& McVaugh, 1980).

In January 1939 Murphy reconsidered and assumed co-editorship of the journal with Bernard

1 Address correspondence to: John Palmer, Ph. D., Rhine Research Center, 2741 Campus Walk Ave., Bldg. 500, Durham, NC 27705, USA, john@rhine.org. 
Riess, primarily to free up Rhine to devote more of his energy to research. He also was encouraged by a policy suggested initially by Rhine, based on a symposium at an American Psychological Association convention, to establish a Board of Review, consisting of 11 psychologists, 5 from New York (including Murphy), 3 from New England, and 3 from the West Coast to review and critique papers published in and submitted to the JP. The January 1939 issue indeed contained articles critical of the research (Mauskopf \& McVaugh, 1980). However, this initial relation between parapsychology and psychology was not sustained.

The December 1938 issue featured a summary of six papers presented at a symposium entitled "Methods in ESP Research" at the recent APA convention (Journal of Parapsychology, 1938). Louis Goodfellow presented a critique of the Zenith Foundation's radio-telepathy experiments. Thomas Greville discussed mathematical and statistical methods in ESP research. Harold Gullickson argued that the cards used in J. B. Rhine's ESP experiments gave off sensory cues; Rhine rebutted Gullickson's criticism. John Kennedy raised the possibility of recording errors in the ESP tests, and Murphy discussed the limitations of this hypothesis.

The September 1939 issue was devoted to a series of papers of a symposium on parapsychology at the 34th Annual Meeting of the Southern Society for Philosophy and Psychology. There were five papers. The first two were discussions of parapsychological statistics by Joseph Greenwood (1939) and Greville (1939), the main statistical consultants of the Parapsychology Laboratory. The second two papers were discussions of parapsychological experimental methods by staff members Pratt (1939) and Charles Stuart (1939). The final paper was by a critic, Vernon Lemmon (1939), who focused on optional stopping artifacts. A panel discussion ensued.

In support of the plan to promote external criticisms of the research, the December 1940 issue featured statistical critiques by Willy Feller (1940) of Brown University, and Douglas Ellison (1940) of Stanford University, with replies by Greenwood and Stuart (1940) and by Pratt (1940) respectively.

In the March 1942 issue, J. B. Rhine (1942) formally announced the resignation of Murphy and Riess as co-editors of the journal, which he attributed to "the complications which [World War II] and parallel developments have introduced for them" (p. 1) without going into further detail. Rhine continued as (primary) editor until 1960, with Pratt as a co-editor. Other co-editors at various times during this period were Stuart, Betty Humphrey, Louisa Rhine, and William Roll.

In the editorial, Rhine also announced the discontinuation of the Board of Review, noting several resignations from the Board and the delays in publication that the reviews caused. He also noted that the JP would begin publishing more "general" articles that less technically sophisticated readers could better comprehend. He also heralded the publication of research reports reflecting the introduction of free-response tests conducted by staff member Stuart and the analysis of card-guessing data for position effects.

The editorial was followed by a review of the first 5 years (volumes) of the JP by Dorothy Pope and Pratt (1942). The most prominent content was original research reports, of which there were 39, but there was an absence of "speculative and theoretical discussion" (p. 5). Across the 5 years there was 
a tendency for the research reports to be shorter, with increasing emphasis on "safeguarding features of methodology" (p. 8), and "fewer cases of an outstanding level of performance" (p. 14). The statistical discussion focused on unjustified data selection and optional stopping. There was also an increasing emphasis of process-oriented issues such as position effects and an introduction of research on precognition. Critics were reluctant to publish their criticisms in the JP, so much of what appeared in the journal in this regard were surveys of criticisms published or presented elsewhere.

In the December 1946 issue J. B. Rhine (1946) wrote an editorial reflecting on the first 10 years of the JP. He bemoaned the facts that the journal operated at a deficit and was not widely read, implying that this was because even with the general articles the journal was a heavy read for the nontechnical reader. On the other hand, he acknowledged that scientific considerations needed to have priority. He also bemoaned that there had been "no overt recognition of the [JPs] contributions to science" (p. 222). In a more positive vein, he noted the expansion of the published research to cover precognition, psychokinesis, "pure telepathy," and personality correlates of ESP, and he reiterated the importance of the research on position effects.

The first two issues of the 1948 JP (Journal of Parapsychology, 1948) were devoted largely to a "symposium" consisting of 19 invited papers presenting the authors' views on "an ideal program for this field of research for the next decade" (p. 1). The authors included seven associated or previously associated with the Parapsychology Laboratory (Edmond Gibson, 1948; Pratt, 1948; Murphy, 1948; Margaret Reeves, 1948; Betty Humphrey, 1948; J. B. Rhine, 1948; J. L. Woodruff, 1948), four from elsewhere in the U.S. (Jan Ehrenwald, 1948; Jule Eisenbud, 1948; Hornell Hart, 1948; Schmeidler, 1948), and eight from Europe, mostly Britain (C. D. Broad, 1948; J. Hettinger, 1948; H. H. Price, 1948; S. G. Soal, 1948; Robert Thouless,1948; G. N. M. Tyrrell, 1948; Rene Warcollier, 1948; D. J. West, 1948). From 1949 through 1951 the JP featured multiple research reports by Soal and associates, and in the March 1954 issue West (1954) published a survey of parapsychological research in Britain.

The first issue of the 1949 JP was devoted to papers and discussion presented at a genuine symposium held by the Society for Parapsychology in Washington, DC. First were four formal papers presented in the morning session on statistical methods by Greville (1949), position effects in ESP and PK data by Pratt (1949), personality correlates of ESP by Schmeidler (1949), and ESP drawing tests by Humphrey (1949). The afternoon session consisted of a roundtable entitled "The Nature of Psi Processes"; the panelists were J. B. Rhine, R. A. McConnell, R. B. Roberts, Greenwood, C. B. Nash, Louisa Rhine, Jan Ehrenwald, and Montague Ullman. The symposium concluded with a paper by Murphy (1949) entitled "The Place of Parapsychology Among the Sciences."

In the March 1950 issue, J. B. Rhine (1950) published an editorial outlining various aspects of the JP's publication policy. He again noted the tension between the need to make sure that research meets the technical scientific requirements of reporting and the need to make the articles readable. He argued that the editor had to give priority to the former requirement while doing as much as possible to meet the second. As for critical articles, Rhine said it was "dangerous" to reject them (p. 6). The editor will make critical comments on the manuscript, but it is up to the author to incorporate these points in a revision. Considerable attention was devoted to the thorny of issue of publishing chance results, and for the most part he justified rejecting them: "If the author has no illuminating observations or conclusions 
to relate and no novel method to describe, the editors feel that there is not space or reader interest enough to justify the publication of a report unless there is the possibility of learning from such a failure" (p. 6). He went on to say that the conclusion that "failure to report a completely fruitless research somehow invalidates the conclusions drawn from significant studies that have been reported" is a "wrong impression" (p. 6). However, he insisted that all the results should be reported from individual studies. Finally, he noted that the results of minor studies cannot always be reported due to space limitations, even if the results are significant.

The December 1955 issue was devoted largely to discussion of an article in the prestigious journal Science by George Price (1955a), who attributed the significant card guessing results in Rhine's and Soal's experiments that could not be accounted for by conventional criticisms to, as Rhine put it in his introductory remarks, "fraud, mental abnormality or incompetence against the research personnel in parapsychology" (p. 238). Following were abstracts of Price's article and replies by P. W. Bridgman (1955), Paul Meehl and Michael Scriven (1955), J. B. Rhine (1955a, 1955b), and Soal (1955), followed by Letters to Science or the JP by James Crumbaugh (1955), Ralph Erickson (1955), Waldron Gardiner (1955), Gibson (1955), Jack Kapchan (1955), McConnell (1955), Ozanne (1955), and Kendon Smith (1955), as well as a brief reply by George Price (1955b) to the original critiques. The exchange ended with summary remarks by J. B. Rhine (1955c).

In the December 1956 issue, J. B. Rhine (1956) published an editorial reviewing the first 20 years of the JP. He began by revealing that a major original purpose of the journal had been "to keep the literature of experimental parapsychology as far as possible assembled in one central location" (p. 263). The rest of the editorial summarized how the scope of the journal had gradually expanded over the years. Whereas at first it was devoted exclusively to publishing evidence for the existence of ESP, it expanded to cover the different types of ESP (telepathy and precognition in addition to clairvoyance), followed in turn by theoretical articles, articles dealing with the personality correlates of ESP, reports of spontaneous cases (to help guide the experimental research), articles on the psychological factors that impact the psi process, and, finally, a "reopening of the question of sprit survival" (p. 264) although not as a primary issue.

The survival theme was reinforced in the March 1960 issue with a section on a symposium held at Duke in 1959 on how to deal with the problem of "incorporeal personal agency." The section began with a listing of the program, but only J. B. Rhine's (1960a) "Opening Remarks" and Louisa Rhine's (1960) paper were reproduced in the issue. The "Opening Remarks" provided a history of the involvement of J. B. Rhine and the Parapsychology Laboratory with the issue. As a justification both for the symposium and for research on the survival question, he noted that since the research on psi had [in his view] established the existence of an "extraphysical" component of personality, it is a logical next step to examine to what degree it may be independent of the physical component. J. B. Rhine (1960b) published a more extensive paper on this topic in the December 1960 issue, where he presented a critical review of past efforts to address the problem and offered suggestions for the future.

At the end of 1957, J. B. Rhine gave up the editorship of the JP. For the next 6 years the editors were Pratt, Louisa Rhine, and William Roll. This was followed by a 13-year period (1964 to 1976) in which the editors were Louisa Rhina and Dorothy Pope. 
The survival theme was in a sense continued in the March 1961 issue with a section discussing a "symposium" on the question of the "physicality of psi." In the introduction section, J. B. Rhine (1961c) reported that he had invited readers to submit 800-1600 word articles addressing specific questions related to this issue. The introduction was followed by "Discussion" pieces by Broad, Cyril Burt, Pratt, and Scriven. In the September 1961 issue "Responses to the Forum" were published by the original contributor Scriven (1961), with replies by Pratt (1961a) and Wolfgang Ehrenberg (1961).

The June 1961 issue featured articles by C. E. M. Hansel explaining how he believed that what he considered to be the two best controlled and potentially evidential card-guessing experiments in the early days of the Parapsychology Laboratory could be explained by fraud-by the subject Pearce in the Pearce-Pratt experiment (Hansel, 1961a) and by one of the experimenters, Woodruff, in the Pratt-Woodruff experiment (Hansel, 1961b). The critiques were followed by a rebuttal by J. B. Rhine and Pratt (1961) in the former case and by Pratt and Woodruff (1961) in the latter. These were followed by an article on position effects in the Pratt-Woodruff series (Pratt, 1961b), which was a crucial component of the defense of that study. In his introduction to the exchange, J. B. Rhine (1961a) noted that he offered Hansel the option of resolving the dispute in private correspondence but Hansel insisted on publication.

For the December 1961 issue, J. B. Rhine (1961b) wrote a 10-page "review" of the first quarter century of the JP. I will refer only to those points that had not been made in earlier reviews. First he praised the major contributions of McDougall in the founding of the journal and the defining of its mission. We also learn that it was McDougall who suggested that the name "parapsychology" appear in the journal's title. Rhine noted that starting in 1942 specialty editors had been added on the editorial page, most notably statistical editors. Greenwood was the first of these, and in 1945 Greville was added. Also begun in 1942 was a book review section for "books of distinctly parapsychological character and of special significance to the field" (J. B. Rhine, 1961, p. 240). In 1946, a kind of newsletter called Parapsychology Bulletin was established. For 10 years it was officially an adjunct of the JP, but after a 1-year discontinuation it resumed in 1957 as a separate publication of the Parapsychology Laboratory until 1965. In 1958, publication of Parapsychological Abstracts commenced, intended "to cover all parapsychological publications-foreign as well as domestic - that would be of value to students and that were not reported in full in the JP" (J. B. Rhine, 1961, p. 241). A major event was the JP becoming affiliated with the recently formed Parapsychological Association (PA). Starting in 1958, the JP began publishing PA "news, programs and abstracts of convention papers" (J. B. Rhine, 1961, p. 241). Finally, Rhine noted that although the JP went out of its way to publish critical articles, this policy did not extend to a critic who in the judgment of the editor was "unqualified or not well enough informed to weigh and argue his criticism" (J. B. Rhine, 1961, p. 244) and he couldn't resist a dig at the bane of all journal editors, the "petty annoyances" (J. B. Rhine, 1961, p. 243) expressed by authors who had their papers rejected.

Beginning in 1969, reports of highly successful psi experiments on rodents by Walter J. Levy began to appear in the JP. Levy was incredibly successful in getting positive results in psi experiments during his short tenure at what was now the Foundation for Research on the Nature of Man (FRNM). The entire 1973 volume included no less than seven reports of Levy's experiments. But then in the June 1974 issue, J. B. Rhine (1974) had to report that members of Levy's research team had uncovered conclusive 
evidence that Levy had created significant results by faking the data in at least one experiment. Levy confessed to Rhine and quickly resigned from FRNM. Although Levy claimed that only this one study was fraudulent, Rhine concluded that judgment on all Levy's research needed to be suspended and that the final verdict would depend on whether the research could be successfully replicated (which it generally was not).

Controversies about important psi experiments never seem to die, and in the June 1974 issue R. G. Medhurst and Scott (1974) published a reanalysis of the data in the Pratt-Woodruff experiment that they claimed supported Hansel's skeptical interpretation. Pratt (1974a) followed with an article challenging Medhurst and Scott's interpretation of the new findings. Responses by Scott (1974) and Pratt (1974b) ensued.

In the June 1975 issue, J. B. Rhine (1975) revisited the question of the JP's policy of not publishing nonsignificant results. His first point was that that a nonsignificant study has no bearing on the interpretation of other, significant studies, so long as the studies are "independent." The second is that nonsignificant results are only informative if the author had previously produced significant results to which the nonsignificant results could be compared. He did, however, leave himself the out that a nonsignificant study might be published if the author could show exactly how the study produced useful information, although the implication was that this had never occurred in the past or was expected in the future.

The article prompted three Letters to the Editor in the March 1976 issue, one by John Beloff, Richard Broughton, and Brian Millar (1976), and the other by Dick Bierman (1976). The key argument in both papers was that Rhine ignored the fact that the significant result could be a type 1 error (de facto chance) and failed replications of the study is how this can be established. Thus, suppression of negative results can lead to an invalid interpretation of the significant studies, even if all the studies are independent. Beloff et al. further suggested that the policy would encourage authors to submit fraudulent data on the grounds that they would not fear publication of a failed replication. A third Letter, by Morgan Eades (1976), an academic psychologist, was also critical of Rhine's article, but made no substantive argument. J. B. Rhine (1976) replied to the Letters in the same issue. First, he reiterated the point that he would publish abstracts of the nonsignificant studies and send full copies to readers upon request. Rhine did not directly address the statistical argument, instead complaining that the critics wanted him to conform to the standards of "hard" sciences such as physics. This is not an argument the letter writers made. He also responded to a fraud argument that is not the one Beloff et al. made: that the motive for faking data would be that a study would have to produce significant results for it to be published. Rhine simply speculated in effect that it is unlikely the author would have this motivation.

In the June 1977 issue, J. B. Rhine (1977) published a paper announcing his retirement as editor of the JP (although, as noted above, he had not been listed as an editor since 1957). Beginning in that year and until 1982, the editor was listed as Dorothy Pope, with K. Ramakrishna Rao listed as co-editor. Pope was the only editor in the entire history of the JP who was not otherwise a researcher or academic and thus could devote full time to her editorial duties.

Rhine's 1977 article was largely an acknowledgement and appreciation of the role of McDougall in establishing both the Parapsychology Laboratory and the JP in a university, and in defining their re- 
spective missions. McDougall's writings were extensively quoted. Toward the end of the article, Rhine speculated about what McDougall would think about how the journal had evolved during the years following his death in 1938. Among the speculations was that McDougall would have liked to see more contributions from authors of stature outside the normal parapsychological sphere and more attention to the relation of psi and parapsychology to other scientific fields and, especially, broader issues such as the mind-body problem. On a more nuts-and-bolts level, Rhine noted that a major problem faced by the field at the time of the JP's founding was that researchers had difficulty getting their psi research published in psychology journals. Conversely, he bemoaned the long-term difficulty he had in keeping the journal filled with quality material, largely because authors outside the field were reluctant to publish in the JP either for political reasons (e.g., job security) or because a publication in a psychology journal would be more prestigious. However, he concluded that the JP, along with the other parapsychology journals, provided enough space to accommodate all publishable parapsychological investigations.

J. B. Rhine died in 1980, and the March 1981 JP was wholly devoted to articles describing his contributions to parapsychology. The first article was by his wife giving a personal perspective on his life and career, focusing on "the personality of J. B. Rhine and his scientific work" (L. E. Rhine, 1981, p. 5). It was followed by an article by Schmeidler (1981) discussing "Rhine's contributions to experimental methodology and his specific innovative methods, and show[ing] how he continuously maintained the highest possible research standards" (p. 11), and an article by John Palmer (1981) on the empirical evidence for ESP accumulated by Rhine and his colleagues. Palmer stated that his purpose was to "highlight the trends which seem to define the evolution of Rhine's approach to ESP research" (p. 25). This was followed by an article by Beloff (1981), the purpose of which was to "expound Rhine's teachings on the nature of psi" (p. 41). The next article, by James Hall (1981) addressed the implications of Rhine's work "for the study of theology and the practice of religion" (p. 55). In the final article, Brian Mackenzie (1981) discussed Rhine's place in the history of parapsychology, "the personal and professional factors involved in J. B. Rhine's major contributions to parapsychology" (p. 81).

In 1983, Rao became the editor of the JP, and in the March 1987 issue he published a series of articles devoted explicitly to the journal. The first article was an editorial in which he briefly reviewed the first 50 years of the JP and set an agenda for the next 50 years (Rao, 1987). The historical review did not say much that had not been said before, but he did note the multiple changes in the editorship of the JP over this period. The prospective section gave a very clear summary of his publication policy, which differed somewhat form Rhine's. Although the main focus would continue to be "on experimental research and empirical findings and their interpretation ... due attention will go to field investigations, case studies, and speculative and scholarly papers of theoretical purport ...." (p. 5). There would also be recognition of the interdisciplinary nature of psi research and inclusion of cross-cultural studies.

Following the editorial was publication of a lecture by Mauskopf (1987). Although the title of the published version referred to the origins of the JP, it was devoted in large part to the founding of the Parapsychology Laboratory and most of the points about the journal had been made in the previous papers about the JP that I describe above. He noted that at first Rhine wanted parapsychology research reports to be published in psychology journals, but that he changed his mind in part due to failure to get his own papers published in such journals. He then decided to establish the JP as "an ongoing publica- 
tion agency that would be immune from the vagaries of outside agencies and priorities" (p. 15). An article by Broughton (1987) on JP publication policy took an historical approach and expanded on points made in previous JP articles on the topic and reviewed above. Not surprisingly, he devoted considerable space to reviewing in a matter-of-fact way the debate on Rhine's policy of not publishing nonsignificant results. He also noted that there was backlash to Rhine's policy, most notably a denunciation of the policy (although not mentioning the JP by name) in a statement by the Parapsychological Association. Finally, Broughton noted that Rao had expanded the use of external referees. Broughton's paper was followed by an exhaustive review by Palmer (1987) of the controversies that had appeared in the JP over the years. It included elaborations of the exchanges that I touch upon briefly earlier in this paper.

The March 1985 issued featured the first of a series of debates about the evidential status of free-response ESP research using the ganzfeld procedure. Following an introduction by editor Rao (1985), Ray Hyman (1985) published a critique of the ganzfeld experiments conducted up to that time, citing specifically reporting biases, multiple analysis artifact, and various procedural flaws, two of which correlated significantly with study outcomes. He concluded with a meta-analysis demonstrating that the successful replication rate is about what would be expected by chance. Charles Honorton (1985) published a meta-analysis of a subsample of ganzfeld experiments to which the multiple analysis artifact did not apply. He found that the results of these studies were highly significant. He challenged Hyman's flaw assignments and none of his own assignments correlated significantly with study outcomes. In the December 1986 issue, Hyman and Honorton (1986) co-authored a "joint communiqué" in which they agreed that the results could not be attributed to chance but disagreed about whether the flaws could account for the significance. Finally, they agreed that the final verdict would depend on the results of future independent replications. The communiqué was sandwiched between 10 other articles commenting on the controversy, by James Alcock (1986), Irvin Child (1986), Gerd Hövelmann (1986), James McClenon (1986), Palmer (1986), Robert Rosenthal (1986), Scott (1986), Rex Stanford (1986), Douglas Stokes (1986), and Jessica Utts (1986).

In 1992, Honorton died suddenly at a young age. His prominence is attested to by the fact that the March and June 1993 issues of the JP were devoted to a review of his career and achievements. Following an introductory paper by Rao (1993) and a personal appreciation and reminiscences by one of Honorton's closest friends, the statistician Donald McCarthy (1993), several articles gave a historical overview of various stages of Honorton's career. James Carpenter (1993) wrote about the time Honorton, Carpenter, and other younger parapsychologists were together at FRNM. Stanley Krippner (1993) reviewed his contributions to the famous Maimonides dream experiments. Mario Varvoglis (1993) reviewed psi research on the ganzfeld procedure and random number generators that Honorton had conducted as Principal Investigator at Maimonides. Ephraim Schechter (1993) then reviewed the more advanced and groundbreaking autoganzfeld research that Honorton conducted at his own laboratory, Psychophysical Research Laboratories. Finally, Robert Morris (1993) discussed Honorton's last days at the University of Edinburgh, where he had enrolled to finally obtain an academic degree.

Other articles, although still historical, were somewhat more topic-focused. Broughton's (1993) article focused on Honorton's methodological contributions, especially the innovative computer games he developed to test psi. Daryl Bem (1993), who coauthored the important autoganzfeld meta-analysis 
that was published in the prestigious Psychological Bulletin, reviewed Honorton's contributions to ganzfeld research and the controversy surrounding it. Statistician Utts (1993) discussed Honorton's contributions to meta-analysis in parapsychology, and Stanford (1993) reviewed Honorton's theoretical and empirical contributions to process-oriented psi research. Palmer (1993) wrote a paper on Honorton's responses to critics of psi research, most notably Hansel's allegations of fraud in prominent psi experiments, as well as mostly statistical critiques by James Kennedy, and, of course, the ganzfeld debate with Hyman. The final two papers were the republication of a broadside against critics of parapsychology by Honorton (1993) himself and a bibliography of his published work by Carlos Alvarado, Rhea White, and Nancy Zingrone (1993).

The December 1989 and March 1990 issues featured a debate among statistician Bernard Gilmore, Utts, and Palmer on problems concerning target randomness in psi experiments, especially RNG experiments. Gilmore $(1989,1990)$ argued that the target sequences used in psi experiments are never truly random: "It is the nature of the concept of randomness that no guarantees of randomness are possible" (p. 329). Thus, participants who receive trial-by-trial feedback could detect the nonrandomness and use it to inflate their scores. He also questioned the validity of standard statistical tests to determine the significance levels and suggested Monte Carlo procedures be used instead. Utts (1989) and Palmer $(1989,1990)$ argued, among other things, that Gilmore never gave a plausible explanation of how the levels of nonrandomness he claimed could influence the results of actual psi experiments. Even if Gilmore were right, any nonrandomness would be so subtle that one could not reasonably expect a participant to detect it.

The December 1999 issue was devoted almost exclusively to an extension and expansion of the ganzfeld debate. A target article by Julie Milton (1999) drew upon an update of a recent ganzfeld meta-analysis by Milton and Wiseman that concluded that the studies aimed at replicating Honorton's successful autoganzfeld studies failed to yield significant overall evidence of psi. She went on to point out methodological flaws that could have accounted for successful meta-analyses of ganzfeld and other methodological paradigms, with particular reference to what she considered to be deficiencies in the quality codes that had been correlated with study outcomes, such that they overestimated the quality of the studies coded. The article was followed by a running commentary on Milton's paper, consisting of 90 messages from 22 commentators (Schmeidler \& Edge, 1999). The commenters were not identified by name until after the 3-week "debate." The subtopics were "Critiques and Defenses of Milton's Conclusion," "Criticisms and Defenses of the [Milton] Presentation and Its Omissions," "Definition of Ganzfeld," "Future Research on the Ganzfeld," "Is Psi Real?" and "The Value of the Debate."

In 1994, Palmer became editor of the JP. Starting in 2000, following a requirement from the PA, he began publishing written versions of Invited Addresses (including Presidential and Banquet Addresses) that were submitted by their authors. Through 2002, with rare exceptions, there continued to be four issues of the journal published each year, listed as March, June, September, and December. To facilitate reducing the almost 1-year publication lag that had developed over the years, in 2003 Palmer shifted to two fatter issues per year, Spring and Fall. To further bring in line the listed and actual publication dates, Palmer published two single issues (Spring/Fall 2008 and Spring/Fall 2009) that were of approximately the same length as single issues; after this the JP reverted to two issues 
per year. This reduced the publication lag to about 3 months and by the time Palmer retired in 2016 it had been reduced to 1 month.

In the 2009 issue, Palmer resumed the practice of publishing editorials in some but not all issues. Some of the editorials were "guest editorials" written by other parapsychologists. In the introduction to the first editorial, Palmer noted that "I envision them as thought-provoking opinion pieces addressing fundamental issues facing contemporary parapsychology" (Palmer, 2009, p. 3).

To commemorate the 75th anniversary of the journal, a special issue was published in December, 2012 (Journal of Parapsychology, 2012). A diverse sample of leading parapsychologists was invited to submit short essays addressing the question "Where will parapsychology be in the next 25 years?" This resulted in 28 essays by 32 authors and co-authors. These were followed by a contribution from Palmer that summarized the essays and gave his own answer to the question. Most of the essays focused on recommendations, more like where parapsychology should be in 25 years.

Finally, in the Fall 2016 issue there appeared a special book review section occasioned by the nearly simultaneous publication of two anthologies taking opposite positions on the mind-body problem: Beyond Physicalism (BP), edited by Edward Kelly et al., and The Myth of An Afterlife (MoA), edited by Michael Martin and Keith Augustine. The idea was to create a debate focused on the issue of postmortem survival by having Stokes (2016a) write a critical review of BP and James Matlock (2016a) write a critical review of MoA. Kelly (2016) and Augustine (2016), the latter supplemented by Claus Larsen (2016) and Ingrid Smythe (2016), then wrote replies to the reviews, followed by replies to the replies by Stokes (2016b) and Matlock (2016b). Palmer (2016) then wrote a discussion section giving his perspective on the points made by the other contributors. The content of the debate was largely philosophical, specifically referencing the competing ontologies aimed at solving the mind-body problem (e.g., materialism, dualism) with secondary reference to the empirical evidence for survival.

In early 2017, I retired as editor of the JP and was replaced by Etzel Cardeña, who described the changes he envisions for the journal in an editorial in the Spring 2017 issue (Cardeña, 2017). The major substantive change will be an expansion in the scope and coverage of the journal. The most important of these changes is an increased emphasis on papers addressing anomalous experiences per se and states of consciousness, studied by non-experimental (presumably qualitative/phenomenological) methods. This adjustment is necessary if for no other reason than to reflect a rapidly evolving change in the primary research objectives (I would go so far as to call it a paradigm shift) within the field of parapsychology, a development I personally find disturbing.

\section{References}

Alcock, J. E. (1986). Comments on the Hyman-Honorton ganzfeld controversy. Journal of Parapsychology, 50, 315-336.

Alvarado, C., White, R., \& Zingrone, N. (1993). Bibliography of the published works of Charles Honorton. Journal of Parapsychology, 57, 215-226.

Augustine, K. (2016). Evidence or prejudice: A reply to Matlock. Journal of Parapsychology, 80, $203-231$.

Beloff, J. (1981). J. B. Rhine on the nature of psi. Journal of Parapsychology, 45, 41-54.

Beloff, J., Broughton, R., \& Millar, B. (1976). [Letter]. Journal of Parapsychology, 40, 88-91. 
Bem, D. J. (1993). The ganzfeld experiment. Journal of Parapsychology, 57, 101-110.

Bierman, D. (1976). [Letter]. Journal of Parapsychology, 40, 91-92.

Bridgman, P. W. (1955). Probability, logic, and ESP. Journal of Parapsychology, 19, 244-245.

Broad, C. D. (1948). A letter from Professor Broad. Journal of Parapsychology, 12, 2-6.

Broughton, R. S. (1987). Publication policy and the Journal of Parapsychology. Journal of Parapsychology, $51,21-32$.

Broughton, R. S. (1993). A craftsman and his tools: The new technology. Journal of Parapsychology, 57, $111-128$.

Cardeña, E. (2017). Whither parapsychology? [Editorial]. Journal of Parapsychology, 81, 6-8.

Carpenter, J. C. (1993). The early parapsychological contributions. Journal of Parapsychology, 57, $25-38$.

Child, I. L. (1986). Comments on the ganzfeld controversy. Journal of Parapsychology, 50, 337-344.

Crumbaugh, J. C. (1955). [Letter]. Journal of Parapsychology, 19, 247.

Eades, M. D. (1976). [Letter]. Journal of Parapsychology, 40, 92-93.

Ehrenberg, W. (1961). Physicality and psi phenomena. Journal of Parapsychology, 25, 216-218.

Ehrenwald, J. (1948). Psychiatry and parapsychology. Journal of Parapsychology, 12, 6-11.

Eisenbud, J. (1948). Psychoanalysis and parapsychology. Journal of Parapsychology, 12, 83-86.

Ellison, D. G. (1940). A criticism of Dr. Pratt's use of Chapman's "statistics of the method of correct matching" in the evaluation of ESP in drawings. Journal of Parapsychology, 4, 329-336.

Erickson, R. W. (1955 ). [Letter]. Journal of Parapsychology, 19, 247-250.

Feller, W. (1940). Statistical aspects of ESP. Journal of Parapsychology, 4, 271-298.

Gardiner, W. R. (1955). [Letter]. Journal of Parapsychology, 19, 250-255.

Gibson, E. P. (1948). A suggested program for parapsychology. Journal of Parapsychology, 12, 86-89.

Gibson, E. P. (1955). [Letter]. Journal of Parapsychology, 19, 255-256.

Gilmore, J. B. (1989). Randomness and the search for psi. Journal of Parapsychology, 53, 309-340.

Gilmore, J. B. (1990). Anomalous significance in pararandom and psi-free domains. Journal of Parapsychology, 54, 53-58.

Greenwood, J. A. (1939). Some mathematical problems for future consideration suggested by ESP research. Journal of Parapsychology, 3, 92- 95.

Grenwood, J. A., \& Stuart, C. E. (1939). A review of Dr. Feller's critique. Journal of Parapsychology, 4, 299-319.

Greville, T. N. E. (1939). A summary of mathematical advances bearing on ESP research. Journal of Parapsychology, 3, 85-92.

Greville, T. N. E. (1949). A survey and appraisal of the statistical methods used in parapsychological research. Journal of Parapsychology, 13, 4-8.

Hall. J. B. (1981). The work of J. B. Rhine: Implications for religion. Journal of Parapsychology, 45, 55-64.

Hansel, C. E. M. (1961a). A critical analysis of the Pearce-Pratt experiment. Journal of Parapsychology, 25, 87-91.

Hansel, C. E. M. (1961b). A critical analysis of the Pratt-Woodruff experiment. Journal of Parapsychology, 25, 99-113.

Hart, H. (1948). Some suggested research projects in parapsychology. Journal of Parapsychology, 12, $12-19$.

Hettinger, J. (1948). A program for the investigation of psychometry. Journal of Parapsychology, 12, 90-95. Hövelmann, G. H. (1986). Beyond the ganzfeld debate. Journal of Parapsychology, 50, 371-376.

Honorton, C. (1985). Meta-analysis of psi ganzfeld research: A response to Hyman. Journal of Parapsychology, 49, 51-92.

Honorton, C. (1993). Rhetoric over substance: The impoverished state of skepticism. Journal of Parapsychology, 57, 191-214.

Humphrey, B. M. (1948). A ten-year program for parapsychology. Journal of Parapsychology, 12, 96-101. 
Humphrey, B. M. (1949). The relation of ESP to mode of drawing. Journal of Parapsychology, 13, 31-46. Hyman, R. (1985). The ganzfeld psi experiment: A critical appraisal. Journal of Parapsychology, 49, 3-50. Hyman, R., \& Honorton, C. (1986). A joint communiqué: The psi ganzfeld controversy. Journal of Parapsychology, 50, 351-364.

Journal of Parapsychology (1938). The ESP symposium at the A. P. A. Journal of Parapsychology, 2, 247272.

Journal of Parapsychology (1948). Symposium: Program for the next ten years of research in parapsychology. Journal of Parapsychology, 12, 1-46, 83-125.

Journal of Parapsychology (2012). Where will parapsychology be in the next 25 years? Predictions and prescriptions by 32 leading parapsychologists [Special issue]. Journal of Parapsychology, 76.

Kapchan, J. (1955). [Letter]. Journal of Parapsychology, 19, 256-258.

Kelly, E. F. (2016). Brief reply to Doug Stokes (and MoA). Journal of Parapsychology, 80, 185-188.

Krippner, S. (1993). The Maimonides ESP dream studies. Journal of Parapsychology, 57, 39-54.

Larsen, C. F. (2016). Response to Matlock. Journal of Parapsychology, 80, 231-232.

Lemmon, V. W. (1939). The role of selection in ESP data. Journal of Parapsychology, 3, 104-106.

Mackenzie, B. (1981). The place of J. B. Rhine in the history of parapsychology. Journal of Parapsychology, 45, 65-84.

Matlock, J. G. (2016a). The myth of mortality: Comments on Martin and Augustine's The Myth of an Afterlife. Journal of Parapsychology, 80, 190-203.

Matlock, J. G. (2016b). Who's prejudice: A reply to Augustine, Smythe, and Larsen. Journal of Parapsychology, 80, 235-250.

Mauskopf, S. H. (1987).The origin of the Journal of Parapsychology. Journal of Parapsychology, 51, 9-20.

Mauskopf, S. H., \& McVaugh, M. R. (1980). The elusive science: Origins of experimental psychical research. Baltimore, MD: Johns Hopkins University Press.

McCarthy, D. (1993). To boldly go: An appreciation of Charles Honorton. Journal of Parapsychology, 57, 7-23.

McClenon, J. (1986). Scientific rhetoric and the ganzfeld debate. Journal of Parapsychology, 50, 371-376.

McConnell, R. A. (1955). [Letter]. Journal of Parapsychology, 19, 258-261.

Medhurst, R. G., \& Scott, C. (1974). A re-examination of C. E. M. Hansel's criticism of the Pratt-Woodruff experiment. Journal of Parapsychology, 38, 163-184.

Meehl, P. E., \& Scriven, M. (1955). Compatibility of science and ESP. Journal of Parapsychology, 19, 243244.

Milton, J. (1999). Should ganzfeld research continue to be crucial in the search for a replicable psi effect? Part I. Discussion paper and introduction to an electronic mail discussion. Journal of Parapsychology [special issue], 63, 309-334.

Morris, R. L. (1993). The last days in Edinburgh. Journal of Parapsychology, 57, 83-88.

Murphy, G. (1949). The place of parapsychology among the sciences. Journal of Parapsychology, 13, $62-71$.

Ozanne, C. E. (1955). [Letter]. Journal of Parapsychology, 19, 262-266.

Palmer, J. (1981). Review of J. B. Rhine's research findings: 1. Extrasensory perception. Journal of Parapsychology, 45, 25-40.

Palmer, J. (1986). Comments on the "joint communiqué." Journal of Parapsychology, 50, 377-382.

Palmer, J. (1987). Controversy and the JP. Journal of Parapsychology, 51, 33-48.

Palmer, J. (1989). A reply to Gilmore. Journal of Parapsychology, 53, 341-344.

Palmer, J. (1990). Reply to Gilmore: Round two. Journal of Parapsychology, 53, 59-62.

Palmer, J. (1993). The psi controversy. Journal of Parapsychology, 57, 177-190.

Palmer, J. (2009). Winning over the scientific mainstream [Editorial]. Journal of Parapsychology, 73, 3-8. 
Palmer, J. (2016). Survival and the mind-body problem. Journal of Parapsychology, 80, 251-257.

Pope, D. H., \& Pratt, J. G. (1942). Five years of the Journal of Parapsychology. Journal of Parapsychology, 6, 5-19.

Pratt, J. G. (1939). A further advance in methods of testing extra-sensory perception. Journal of Parapsychology, 3, 95-100.

Pratt, J. G. (1940). Comment on Dr. Ellison's criticism. Journal of Parapsychology, 4, 337-338.

Pratt, J. G. (1948). Program for parapsychology. Journal of Parapsychology, 12, 20-25.

Pratt, J. G. (1949). The meaning of performance curves in ESP and PK test data. Journal of Parapsychology, 13, 9-23.

Pratt, J. G. (1961a). Comments on Dr. Scriven's comments. Journal of Parapsychology, 25, 216.

Pratt, J. G. (1961b). Run salience in the Pratt-Woodruff series. Journal of Parapsychology, 25, 130-135.

Pratt, J. G. (1974a). Comments on the Medhurst-Scott criticism of the Pratt-Woodruff experiment. Journal of Parapsychology, 38, 185-201.

Pratt, J. G. (1974b). Reply to Dr. Scott. Journal of Parapsychology, 38, 207-214.

Pratt, J. G., \& Woodruff, J. L. (1961). Refutation of Hansel's allegation concerning the Pratt-Woodruff series. Journal of Parapsychology, 25, 114-129.

Price, G. R. (1955a). Science and the supernatural. Journal of Parapsychology, 19, 238-241.

Price, G. R. (1955b). Where is the definitive experiment? Journal of Parapsychology, 19, 245.

Price, H. H. (1948). Future work in parapsychology-some suggestions. Journal of Parapsychology, 12, 25-31.

Rao, K. R. (1985). The ganzfeld debate: Introduction. Journal of Parapsychology, 50, 1-2.

Rao. K. R. (1987).The Journal of Parapsychology: The first and the next fifty years [Editorial]. Journal of Parapsychology, 51, 1-8.

Rao, K. R. (1993). Charles Honorton: A savant of his own kind. Journal of Parapsychology, 57, 1-6.

Reeves, M. P. (1948). Concerning a program for parapsychology Journal of Parapsychology, 12, 31-32.

Rhine, J. B. (1942). The change in editorship and the new program [Editorial]. Journal of Parapsychology, $6,1-4$.

Rhine, J. B. (1946). The first ten years of the journal [Editorial]. Journal of Parapsychology, 10, 221-223.

Rhine, J. B. (1948). Research aims for the decade ahead. Journal of Parapsychology, 12, 101- 107.

Rhine, J. B. (1950). Publication policy [Editorial]. Journal of Parapsychology, 14, 1-8.

Rhine, J. B. (1955a). Comments on "Science and the Supernatural." Journal of Parapsychology, 19, 242243.

Rhine, J. B. (1955b). The experiment should fit the hypothesis. Journal of Parapsychology, 19, 246.

Rhine, J. B. (1955c). Editorial comment: The balance of the view. Journal of Parapsychology, 19, $267-271$.

Rhine, J. B. (1956) The Journal's first 20 years [Editorial]. Journal of Parapsychology, 20, 263-266.

Rhine, J. B. (1960a). Chairman's opening remarks and introduction of the first speaker. Journal of Parapsychology, 24, 2-7.

Rhine, J. B. (1960b). Incorporeal personal agency: The prospect of a scientific solution. Journal of Parapsychology, 24, 279-309.

Rhine, J. B. (1961a). A controversy over charges of fraud in ESP: Editorial introduction. Journal of Parapsychology, 25, 86.

Rhine, J. B. (1961b). A quarter-century of the Journal of Parapsychology: A brief review. Journal of Parapsychology, 25, 237-246.

Rhine, J. B. (1961c). Physicality and psi: A symposium and forum discussion: Editorial introduction. Journal of Parapsychology, 25, 13.

Rhine, J. B. (1974). Comments: A new case of experimenter unreliability. Journal of Parapsychology, 38, 
215-225.

Rhine, J. B. (1975). Comments: Publication policy regarding nonsignificant results. Journal of Parapsychology, 39, 135-142.

Rhine, J. B. (1976). Comments: Publication policy on chance results: Round two. Journal of Parapsychology, 40, 64-68.

Rhine, J. B. (1977). A backward look on leaving the JP. Journal of Parapsychology, 41, 89-102.

Rhine, J. B., \& Pratt, J. G. (1961). A reply to the Hansel critique of the Pearce-Pratt series. Journal of Parapsychology, 25, 92-98.

Rhine, L. E. (1960). The evaluation of non-recurrent psi experiences. Journal of Parapsychology, $24,8-25$. Rhine, L. E. (1981). J. B. Rhine: Man and scientist. Journal of Parapsychology, 45, 5-10.

Rosenthal, R. (1986). Meta-analytic procedures and the nature of meta-analysis. Journal of Parapsychology, 50, 315-336.

Schechter, E. I. (1993). Psychophysical Research Laboratories. Journal of Parapsychology, 57, $67-82$.

Schmeidler, G. R. (1948). Research projects in parapsychology. Journal of Parapsychology, 12, 107-113.

Schmeidler, G. R. (1949). Personality correlates of ESP as shown by Rorschach studies. Journal of Parapsychology, 13, 23-31.

Schmeidler, G. R. (1981). Rhine's contributions to experimental methodology and standards of research. Journal of Parapsychology, 45, 11-24.

Schmeidler, G. R., \& Edge, H. (1999). Should ganzfeld research continue to be crucial in the search for a replicable psi effect? Part II: edited ganzfeld debate. Journal of Parapsychology [special issue], 335388.

Scott, C. (1974). The Pratt-Woodruff experiment: Reply to Dr. Pratt's comments. Journal of Parapsychology, 38, 202-206.

Scott, C. (1986). Comment on the Hyman-Honorton debate. Journal of Parapsychology, 50, 349-350.

Scriven, M. (1961). Discussion of Dr. Pratt's paper. Journal of Parapsychology, 25, 214-215.

Scriven, M., Broad, C. D., Pratt, J. G., \& Burt, C. (1961). Physicality and psi: A symposium and forum discussion. Journal of Parapsychology, 25, 13-31.

Smith, K. (1955). [Letter]. Journal of Parapsychology, 19, 266.

Smythe, I. H. (2016). Replying to Matlock. Journal of Parapsychology, 80, 232-234.

Soal, S. G. (1948). The next ten years in England. Journal of Parapsychology, 12, 32-36.

Soal, S. G. (1955). On "Science and the Supernatural." Journal of Parapsychology, 19, 241-242.

Stanford, R. G. (1986). Commentary on the Hyman-Honorton joint communiqué. Journal of Parapsychology, 50, 383-388

Stanford, R. G. (1993). Learning to lure the rabbit: Charles Honorton's process-relevant ESP research. Journal of Parapsychology, 57, 129-176.

Stokes, D. M. (1986). Replication as a political process. Journal of Parapsychology, 50, 389-392.

Stokes, D. M. (2016a). The elusiveness of souls: An essay review of Beyond Physicalism. Journal of Parapsychology, 80, 169-185.

Stokes, D. (2016b). Reply to Ed Kelly. Journal of Parapsychology, 80, 188-190.

Stuart, C. E. (1939). Some unsolved problems of methodology Journal of Parapsychology, 3, 100-104.

Thouless, R. H. (1948). A program of parapsychology. Journal of Parapsychology, 12, 113- 119.

Tyrell, G. N. M. (1948). Parapsychology: Position, program, outlook. Journal of Parapsychology, 12, 36-41.

Utts, J. (1986). The ganzfeld debate: A statistician's perspective. Journal of Parapsychology, 50, 393-402.

Utts, J. (1989). Randomness and randomization tests: A reply to Gilmore. Journal of Parapsychology, 53, 345-351.

Utts, J. (1993). Honorton the meta-analyst. Journal of Parapsychology, 57, 89-100.

Varvoglis, M. P. (1993). Ganzfeld and RNG research. Journal of Parapsychology, 57, 55-66. 
Warcollier, R. (1948). Suggestions for experiments in parapsychology. Journal of Parapsychology, 12, 119-123.

West, D. J. (1948). Future aims in parapsychology experiments. Journal of Parapsychology, 12, 42-46.

West, D. J. (1954). Experimental parapsychology in Britain: A survey of recent work. Journal of Parapsychology, 18, 10-31.

Woodruff, J. L. (1948). Some basic problems for parapsychological research. Journal of Parapsychology, 12,123-125.

\section{Années du Journal of Parapsychology: Un Tour d'horizon Historique}

Résumé : Dans cet article invité, l'auteur passe en revue l'histoire du Journal of Parapsychology depuis son point de départ en 1937 jusqu'en 2017. L'accent est mis sur les controverses et les débats avec les critiques extérieures au champ de la parapsychologie qui y furent publiés, ainsi que sur la politique du publication du JP et les changements de comité éditorial.

\section{Jahre Journal of Parapsychology: Ein historischer Überblick}

Zusammenfassung: In diesem eingeladenen Artikel beleuchtet der Autor die Geschichte des Journal of Parapsychology von seiner Gründung 1937 bis 2017. Der Schwerpunkt liegt auf veröffentlichten Kontroversen und Debatten mit Kritikern von außerhalb der Parapsychologie, der Publikationspolitik des JP und den Veränderungen in der Herausgeberschaft.

\section{Años del Journal of Parapsychology: Un Panorama Histórico}

Resumen: En este artículo, el autor pormenoriza la historia del Journal of Parapsychology desde su inicio en 1937 hasta 2017. El foco son las controversias publicadas y debates con los críticos externos a la parapsicología, la política de publicación del JP, y los cambios de editores. 